\title{
PENGERTIAN ART DIRECTION DAN PERANAN SEORANG ART DIRECTOR DALAM PERIKLANAN
}

\author{
Aryo Bimo \\ Jurusan Desain Komunikasi Visual, Fakultas Komunikasi dan Multimedia, \\ Bina Nusantara University, Jln. K.H. Syahdan No. 9, Palmerah, Jakarta Barat 11480 \\ obeems@binus.edu
}

\begin{abstract}
Nowadays advertising is a field that is progressing rapidly and is quite popular majors marked by numerous educational institutions both private and the country that opened specialization advertising. One of the positions in the field of advertising that quite popular is Art Director. The skill of art directing is a bit much has been represented in the department of Visual Communication Design or Graphic design. But it is sometimes still confused between the duties and role of an art director and a graphic designer. This article gives a general overview of what is meant by Art Director as well as roles and duties.
\end{abstract}

Keywords: art direction, art director, advertising

\begin{abstract}
ABSTRAK
Dewasa ini periklanan merupakan bidang yang cukup mengalami perkembangan yang cukup pesat dan merupakan jurusan yang cukup diminati ditandai dengan banyaknya institusi pendidikan baik swasta maupun negeri yang membuka peminatan periklanan. Salah satu jabatan di bidang periklanan yang cukup diminati adalah Art Director. Ilmu mengenai art directing memang sedikit banyak sudah terwakili oleh jurusan Desain Komunikasi Visual atau desain Grafis. Namun kadang masih rancu antara tugas dan peranan seorang Art Director dan seorang desainer grafis. Tulisan ini memberikan gambaran secara umum mengenai apa yang dimaksud dengan Art Director begitu pula peranan dan tugasnya.
\end{abstract}

Kata kunci: art direction, art director, periklanan 


\section{PENDAHULUAN}

Periklanan atau advertising di Indonesia sudah mengalami booming yang cukup signifikan di era 90an dan awal 2000-an. Perkembangan ini ditandai juga dengan makin maraknya institusi pendidikan yang membuka jurusan advertising atau periklanan. Baik itu yang setara dengan D3 maupun S1, negeri maupun swasta.

Art Director adalah satu jabatan dari sekian banyak jabatan yang ada di bidang periklanan. Art Director merupakan salah satu jurusan yang cukup diminati oleh anak-anak DKV. Oleh karena itu tulisan ini sedikit ingin memberikan gambaran mengenai apa sebenarnya peranan dan tugas seoarang Art Director. Pada kesempatan ini pembahasan Art Director lebih difokuskan pada bidang periklanan.

\section{METODE PENELITIAN}

Penelitian ini dilakukan dengan studi literatur yaitu mencari berbagai sumber yang terkait seperti pustaka maupun media internet. Kemudian diseleksi dan dijadikan pendukung penulisan artikel ini.

\section{PEMBAHASAN}

\section{Art Direction}

Pekerjaannya sendiri disebut dengan Art Direction. Pengertian dari Art Direction secara umum adalah proses mengarahkan elemen visual (art) dalam semua bentuk media komunikasi baik itu film, program TV, digital, iklan. Dalam pengertian ini Art Direction adalah kegiatan yang memiliki aplikasi yang lebih luas di berbagai disiplin ilmu yang terkait dengan komunikasi visual.

Secara mendasar, Art Direction melibatkan mendesain tampilan dari iklan tersebut. Namun lebih dari sekadar pertimbangan estetika. Tidak hanya sekedar bagaimana membuat iklan tersebut terlihat bagus. Karena pada akhirnya, semua elemen visual sebuah iklan harus bekerja bersama-sama untuk memaksimalkan dampak pesan iklan itu sendiri. Hal ini bisa diartikan bahwa beberapa prinsipprinsip dalam desain grafis maupun aturan estetika kadangkala diabaikan demi untuk mencapai tujuan komunikasi.

\section{Art Director}

Art Director adalah orang yang bertanggung jawab dengan semua hal yang berkenaan dengan artistik, visual dan non verbal. Namun walaupun seorang Art Director, sesuai namanya, bertangung jawab dengan hal visual bukan berarti dia sama sekali tidak memperhatikan segi verbal. Art Director biasanya berasal dari lulusan Desain Komunikasi Visual atau Desain Grafis walaupun tidak menutup kemungknan juga dari disiplin ilmu lain yang kadang tidak berhubungan dengan dunia seni dan desain.

Namun pengetahuan mengenai disiplin ilmu Desain Komunikasi Visual atau Desain Grafis sebenarnya sangatlah penting, karena sedikit banyak seorang Art Director akan berurusan dengan halhal yang berkenaan dengan desain grafis seperti (1) tipografi, pengetahuan yang baik mengenai tipo seperti karakteristik huruf, anatomi huruf; (2) fotografi, pengetahuan dasar yang baik mengenai 
fotografi seperti pencahayaan, komposisi; (3) komposisi dan Tata letak, pengetahuan dasar yang baik mengenai tata letak dan komposisi seperti bagaimana mendesain dan mengkomposisikan sebuah halaman dimana terdapat elemen visual, elemen teks dan elemen grafis lainnya; (4) warna, pengetahuan dasar mengenai warna yang baik seperti jenis warna, psikologis warna.

Hal- hal yang harus dimiliki seorang Art Director selain pengetahuan dalam ilmu DKV adalah memiliki kemampuan interpersonal dan etos kerja yg baik; memiliki kemampuan berpikir konseptual; bisa bekerja sama dalam tim, mengerti tentang desain, fotografi, tipografi, proses cetak; memiliki ketertarikan dalam berbagai hal seperti: trend, masalah sosial, budaya, fashion, pasar dan lainnya; siap menghadapi tenggat waktu yg cukup ketat; siap bekerja di bawah tekanan.

Sering kita lihat pada iklan lowongan kerja yang mencari seorang Senior Art Director dengan salah satu kualifikasinya adalah minimal berpengalaman 1 sampai 2 tahun. Apakah ukuran lama 1 tahun ini sudah pantas seorang Art Director disebut sebagai Senior? Kapankah seorang Art Director sudah layak disebut sebagai Senior? Jenjang jabatan Art Director kalau dibagi berdasarkan pengalaman dan lama bekerja bisa dikategorikan menjadi Junior Art Director, Art Director, dan Senior Art Director.

Junior Art Director biasanya adalah mereka yg baru lulus dari kuliah atau istilahnya Fresh Graduate atau yang belum lama bekerja sebagai seorang Art Director. Katakanlah 1 sampai 2 tahun. Tidak adanya standar acuan yang jelas dalam bidang periklanan kita membuat rentang jabatan seorang Art Director kadang menjadi rancu.

\section{Tugas dan Wewenang Art Director}

Art Director memang tidak melulu milik departemen kreatif sebuah perusahaan periklanan. Namun yang pasti tugas seorang Art Director adalah berurusan sesuatu yang berkenaan dengan visual, artistik dan non verbal. Dalam periklanan seorang Art Director selain berurusan dengan visual dia juga hrus bisa berpikir konseptual. Bagaimana memvisualisasikan sebuah ide atau konsep ke dalam bentuk sebuah iklan baik itu cetak maupun audio visual. Karena pada akhirnya seorang Art Director harus menentukan seperti apa arahan artistic maupun visual dengan disesuaikan brief dan target audiensnya.

Seorang Art Director sejatinya membawahi beberapa desainer grafis yang akan membantunya dalam memvisualisasikan suatu konsep iklan. Jabatan Art Director juga dikenal di bidang kreatif lainnya seperti griya produksi, penerbitan, majalah, griya desain. Jabatan Art Director tentunya sudah dikenal oleh para praktisi periklanan maupun desain grafis. Tetapi bagi kalangan masyarakat awam terkadang masih menimbulkan kerancuan. Kata "Director" selalu disalah artikan sebagai "direktur" atau pimpinan sebuah perusahaan atau departemen.

Art Director sendiri dalam bahasa Indonesia diterjemahkan sebagai "Pengarah Seni”. Karena sesuai namanya seorang Art Director memang bertugas untuk mengawasi, mensupervisi dan memberikan arahan mengenai artistik, visual dalam proses pembuatan sebuah iklan atau desain. Pada dasarnya seorang Art Director memang harus memikirkan tampilan sebuah iklan agar terlihat menarik. Namun tidak hanya sekedar faktor estetika maupun artistik saja namun yang terpenting adalah bagaimana sebuah iklan tersebut bisa mengkomunikasikan pesan terhadap khalayak sasarannya.

Art Director dalam struktur perusahaan periklanan ada dalam departemen bernama departemen kreatif. Seorang Art Director akan dipasangkan dengan seorang Copywriter atau penulis naskah. Maka kerap mereka juga disebut sebagai tim 'kreatif'. Pada awalnya seorang Art Director dan Copywriter bekerja secara terpisah. Namun pada perkembangannya kedua orang ini harus bisa bersinergi secara bersama-sama bertanggung jawab untuk menghasilkan sebuah ide kreatif maupun ide sebuah kampanye sebuah iklan. Jadi keduanya harus saling melengkapi dan tidak ada yang lebih 
unggul dari yang lainnya. Karena pada dasarnya di periklanan adalah merupakan kerja tim bukan hasil kerja perseorangan, jadi kerjasama tim memegang peranan yang cukup penting. Paradigma kerja tim ini yang kadang ter”lupa”kan oleh mereka termasuk praktisi periklanan sendiri. Karena sebuah iklan atau sebuah kampanye iklan tidak akan lahir hanya dari satu orang saja. Melainkan adalah hasil kerja dari tim yang menangani kampanye iklan tersebut.

Seorang Art Director pada masa sekarang ini pun tidak lagi hanya berkutat seputar urusan visual ataupun estetis tapi dia juga hendaknya memiliki kemampuan berpikir copy juga secara global. Begitu pula sebaliknya, seorang Copywriter juga tidak melulu mengurusi soal teks, headline dan tagline saja. Tantangannya adalah bagaimana supaya tampilan sebuah iklan bisa begitu menraik secara visual dan artistic tapi disisi lain juga tetap tidak melupakan sisi komunikasinya. Pesan apa yang ingin disampaikan kepada khalayak sasarannya. Selain itu juga ada beberapa unsur lagi yang perlu dipertimbangkan seperti karakteristik produk yang diiklankan, siapa target audiens dari iklan tersebut, untuk strata ekonomi sosial mana iklan tersebut ditujukan, atau sudahkah iklan tersebut menjawab "problema" target audiens.

Secara hirarki jabatan posisi Art Director disebuah perusahaan periklanan biasanya berada diatas desainer grafis. Jadi seorang Art Director biasanya membawahi beberapa desainer grafis yang akan membantu mengeksekusi atau memvisualisaikan konsep-konsep visual. Seorang desainer grafis memang lebih condong ke pekerjaan yang bersifat eksekusional berdasarkan arahan dan brief dari seorang Art Director. Itulah yang menjadi sedikit perbedaan antara seorang Art Director dan seorang Desainer Grafis walaupun dari segi skill dan tugas tidak terlalu berbeda. Berikut skema struktur hirarki Art Director dalam perusahaan periklanan (Gambar 1):

\section{departemen kreatif}

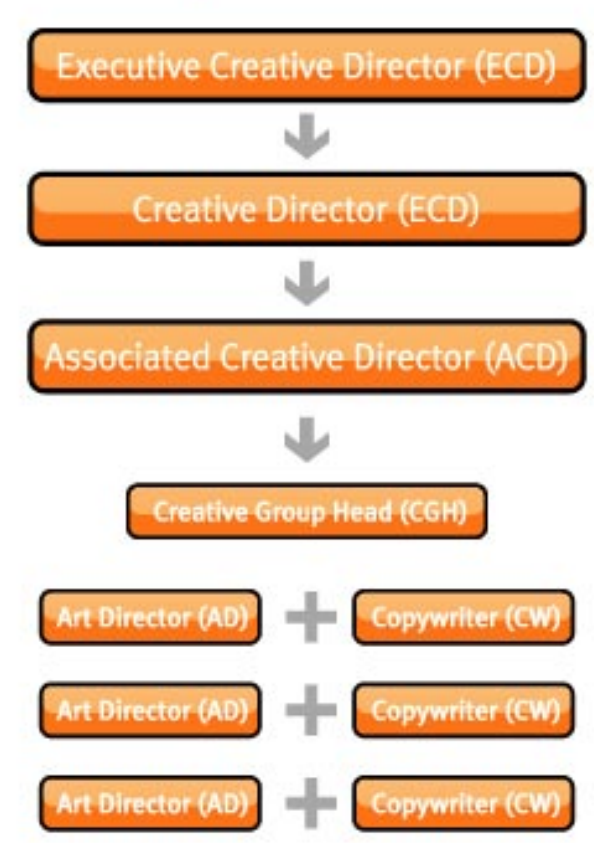

Gambar 1 Strusktur jabatan di departemen kreatif

Berikut beberapa contoh iklan dimana peran Art Director sangat menetukan sekaligus dapat memberikan sedikit gambaran mengenai apa yang dikerjakan oleh seorang Art Director (Gambar 2). 


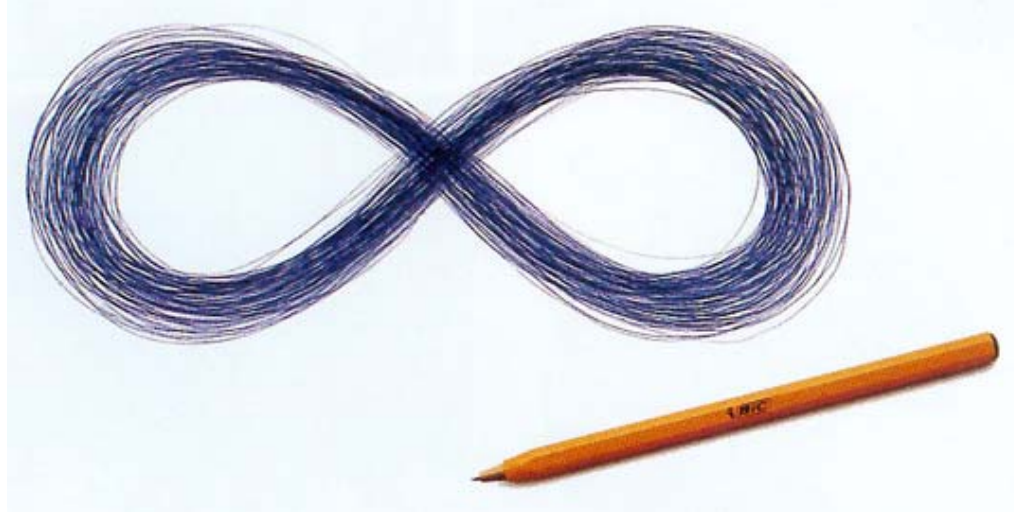

Gambar 2 Iklan cetak BIC

Sumber: http://adsoftheworld.com/media/print/bic_infinity

Iklan cetak BIC buatan biro iklan TBWA ini merupakan salah satu iklan dengan Art Direction yang cukup baik. Karena menggambarkan benefit dari produknya secara gamblang dan jelas. Tanpa harus ada headline maupun copy karena dari segi visual sudah kuat sekali.

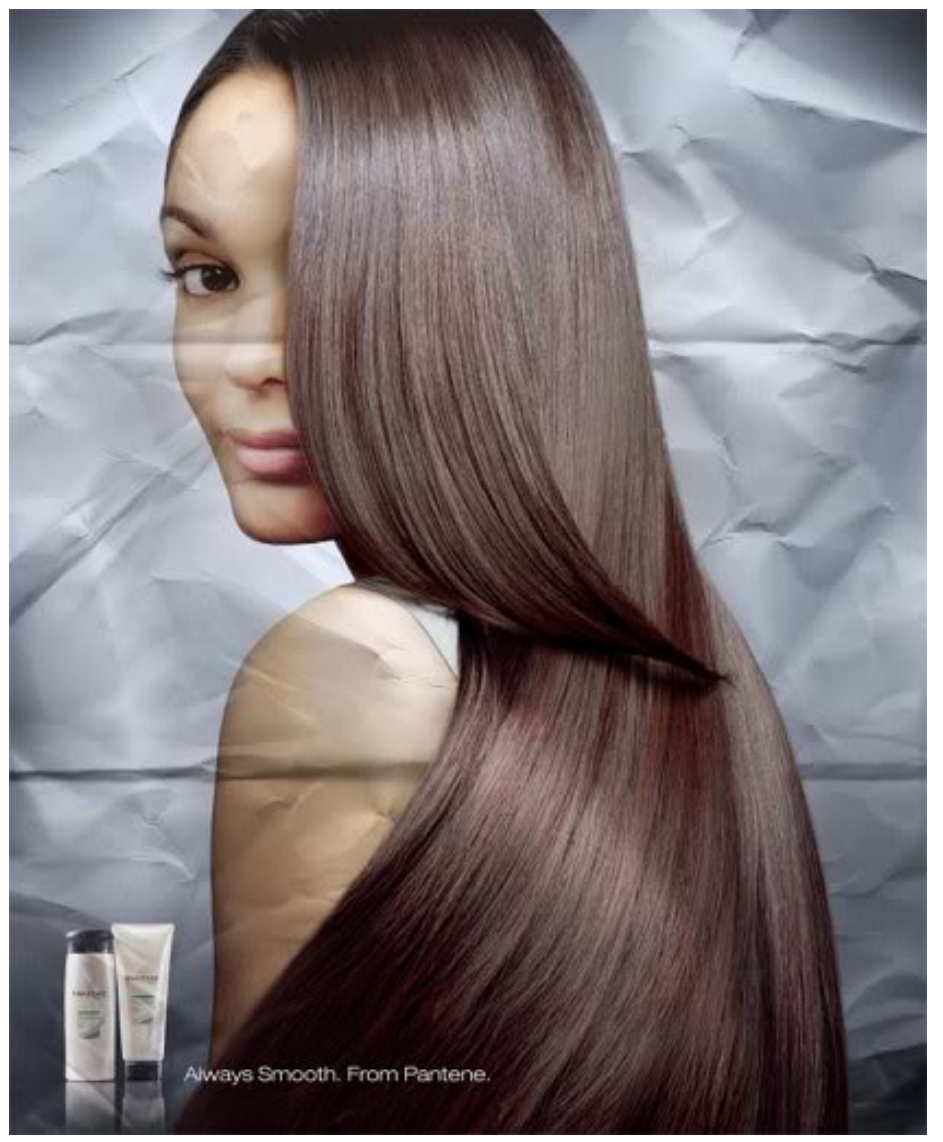

Gambar 3 Iklan cetak sampo Pantene Pro-V

Sumber: http://www.usernetsite.com/advertisement/pantene-pro-v.php

Iklan cetak Pantene Pro V buatan biro iklan TBWA ini juga menggunakan Art Direction yang cukup cerdik dan secara gamblang menjelaskan manfaat dan kegunaan dari produk tersebut. 


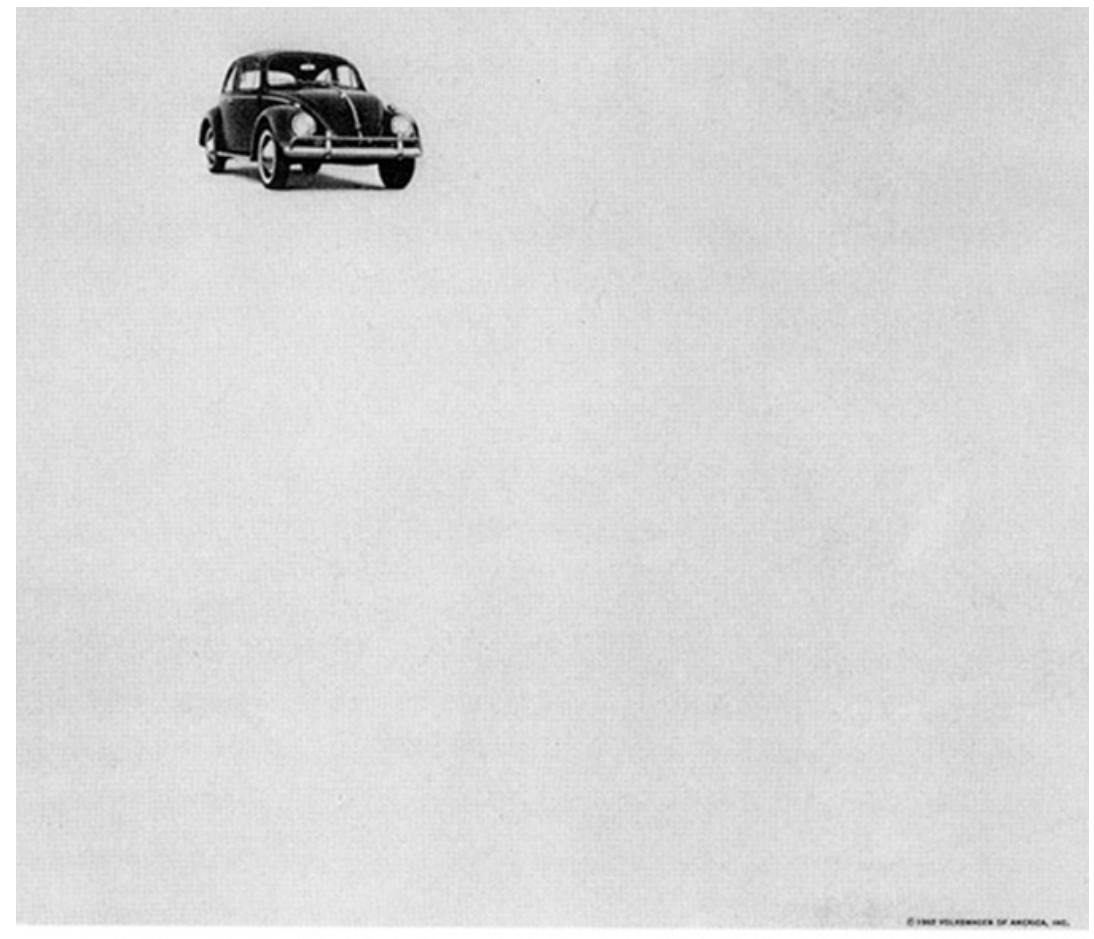

Think small.

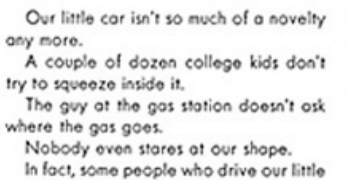

Airver don't even think 32 miles 10 the gol. is going ony greol guns

pints of oil insteod of fivo

poring Or nover noeding onti.freezo. tires.

tires.
That's becouse once you get urad to

some of our economies, you don't even thin obout them ony more.

Except whion you squeezo into o smoll apor. Or renow your smoll insuronce. Or poy o moll ropoir bill. your old $\mathrm{VW}$ for a Think it over.

Iklan VW “Think Small” (Gambar 4) buatan biro iklan DDB tahun 1959. Iklan ini merupakan salah satu iklan cetak yang cukup legendaries. Walaupun sebenarnya kekuatan iklan ini terletak pada headline dan bodycopynya namun pada era tersebut layout ini merupakan sebuah terobosan. Iklan cetak dengan layout yang cukup minimalis menjadikan iklan VW karya DDB ini merupakan iklan cetak yang cukup fenomenal pada jamannya. Tentunya ini juga didukung dengan art direction yang cukup baik.

\section{KESIMPULAN}

Dari penjelasan diatas kiranya dapat kita lihat bahwa peranan Art Director dalam iklan memang cukup penting dan sangat menentukan bagaimana tampilan dan artistiknya sebuah iklan. Namun perlu dicatat bahwa kemampuan berpikir konspetual memang memegang peranan yang cukup penting selain kemampuan skill maupun kemampuan desain komunikasi visual. 


\section{DAFTAR PUSTAKA}

Burtenshaw, K., Mahon, N., \& Barfoot, C. (2006). The Fundamentals of Creative Advertising, Ava Academia. London: Ava Publishing.

Mahon, N. (2010). Basics Advertising: Art Direction. London: Ava Publishing. 